\title{
Histo-Pathologic Study of Burn Cases and Its Role in Assessment of Duration of Injuries
}

\author{
Bhim Singh ${ }^{1 *}$, Srivastava AK ${ }^{2}$ \\ ${ }^{1}$ Associate Professor, ${ }^{2}$ Professor\& Head, Department of Forensic Medicine, Subharti Medical College, Meerut, UP, INDIA.
}

\begin{abstract}
Burn in restricted sense is caused by application of dry heat. In this study most of the casualties (84.61\%) occur by kerosene oil either by overflow of pressure stove $(51.92 \%)$ or by deliberate throwing of kerosene oil and igniting with match stick (32.69\%).

Histo-pathological changes were studied here in skin, lungs, liver, and kidneys in 52 cases died due to burn at different intervals, just after burn injuries (on the spot) to 21 days. Congestion and edema were seen in all the tissues and in almost all the cases. Lymphocytic infiltration and granulation tissue formation were seen in skin tissues in cases died 24 hours and 5 days after burn injuries respectively. Bronchopneumonia and haemorrhages appeared in lung between 1224 hours after burn and emphysema, consolidation and atelectasis after 3 days. In liver portal triradiatis appeared 12 hours after burn, fatty degeneration after 24 hours and lymphocytic infiltration \& centri-venous necrosis after 2 days. Cloudy swelling \& acute tubular necrosis appeared in kidneys
\end{abstract}

\section{INTRODUCTION}

Burn is one of the commonest causes of unnatural deaths in our country. It may caused by flame, heated solid objects, boiling liquids, electricity, X-rays \& ultra violet radiations and corrosive substances but practically burn is restricted to injuries caused by dry heat such as flame or heated solid objects ${ }^{1}$. Skin and fleshes are almost non-inflammable, catches fire with difficulty but clothing, hair and human fats facilitate it. When skin is exposed to moderately high temperature pain, redness and swelling appears almost immediately and when heating continues epidermis separates from dermis to form blisters and if still goes on charring and coagulation necrosis occur.

At cellular level the cells of deeper layer of epidermis becomes elongated and polymorpho-nuclear leucocytic infiltration in the dermis within few hours. Epithelial cells swollen pale and ballooned with vacuole formation ${ }^{2}$. Changes are not only found in skin but also in other systemic organs such as lungs \& respiratory passage, liver, kidneys, brain etc. and continue till the full recovery or the death.

There are sufficient literatures available on epidemiological and medico- legal aspects of burn injuries but few on histopathology. That's why this project is taken to study histo-pathological changes in organs and tissues due to burn injuries and attempt is also made to find out causes of death and time of survival.

\section{MATERIALS AND METHODS}

Materials for this study were the cases died due to burn injuries and brought to the mortuary of Maulana Azad Medical College within 24 hours and lymphocytic infiltration \& hemorrhages 2 days after burn.

Key words: Acute tubular necrosis, Congestion, Fatty degeneration, Lymphocytic infiltration, Pulmonary edema.

\section{*Correspondence to:}

Dr. Bhim Singh, Associate Professor, Department of Forensic Medicine, Subharti Medical College Meerut, UP.

Email: bhimsinghmamc@yahoo.co,in

Article History:
Received: 26-03-2016, Revised: 04-04-2016, Accepted: 22-04-2016
\begin{tabular}{|l|c|}
\hline \multicolumn{2}{|c|}{ Access this article online } \\
\hline Website: & Quick Response code \\
www.ijmrp.com & \\
\hline DOI: & \\
10.21276/ijmrp.2016.2.3.021 & \\
\hline
\end{tabular}

and associated Hospitals, New Delhi for medico-legal autopsies during 2008-09. After consent from the legal heir, tissues from skin, lungs, liver and kidneys, were collected from 52 dead bodies irrespective of their age and sex and processed for histopathological examination.

After staining with Haemotoxylin and Eosin the slides are examined under microscope and all the findings are recorded on performa which further analyzed and presented in observation and result.

\section{OBSERVATIONS AND RESULTS}

In this study majority of the victims were females (78.84\%) and between $21-30$ years of age (48.07\%). There were only one baby below 10 year and no one above 50 years of age (Table 1). Kerosene oil was responsible for most $(84.61 \%)$ of the burn casualties, of which overflow/ burst of pressure stoves in $51.92 \%$ and strong suspicion of pouring kerosene oil and igniting with match stick in $32.69 \%$ cases (Table 2). More than half $(57.67 \%)$ of the victims died in first 24 hours, of which $3.84 \%$ died on the spot and $53.84 \%$ within 24 hours after getting burn injuries, (Table 3). It was also observed that the victims died earlier had more extensive burn injuries than those survived for more days. On histo-pathological examination, congestion was seen in almost all the tissues and inflammatory changes more pronounced with due course of time. In skin, loss of epidermis was seen in80.76\%, loss of dermis in $11.53 \%$ and deep burns in $07.79 \%$ cases. Congestion and edema of the underlying zone was observed in 
almost all (98.08\%) the cases, lymphocytic infiltration in $46.16 \%$ mostly when victims survived for more than 24 hours and granulation tissue formation in $9.61 \%$ cases after five days.

In lungs, besides congestion and soot particles, pulmonary edema was the most significant finding, seen in $73.08 \%$ cases, especially in those who were survived for more than 12 hours. The evidence of bronchopneumonia was seen in $36.5 \%$ and hemorrhage in $28.8 \%$ mostly in victims died within 1-3 days after burn. Pulmonary infections and consolidation were found in $17.31 \%$, emphysema in $25 \%$ and atelectasis in $3.84 \%$ burns when survived for more than 3 days.

In liver, congestion was the commonest histo-pathological finding

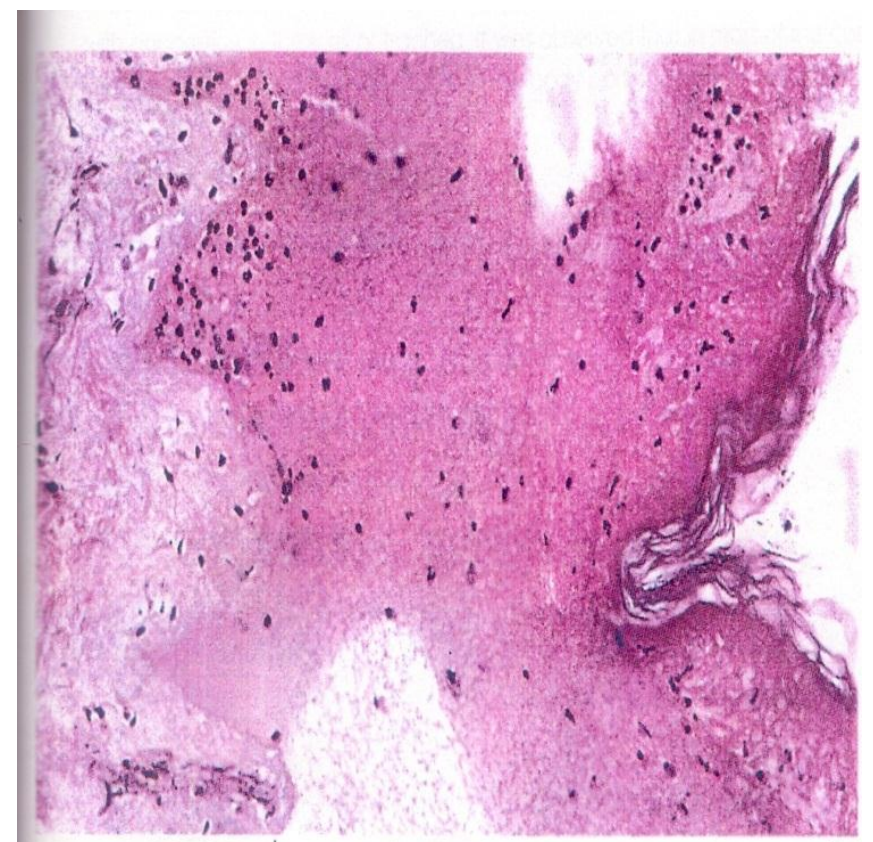

Fig 1: Photomicrograph of Skin-showing necrosis of the epidermis, marked edema of the dermis and dermal infiltration by leucocyte, survival period 2 days.

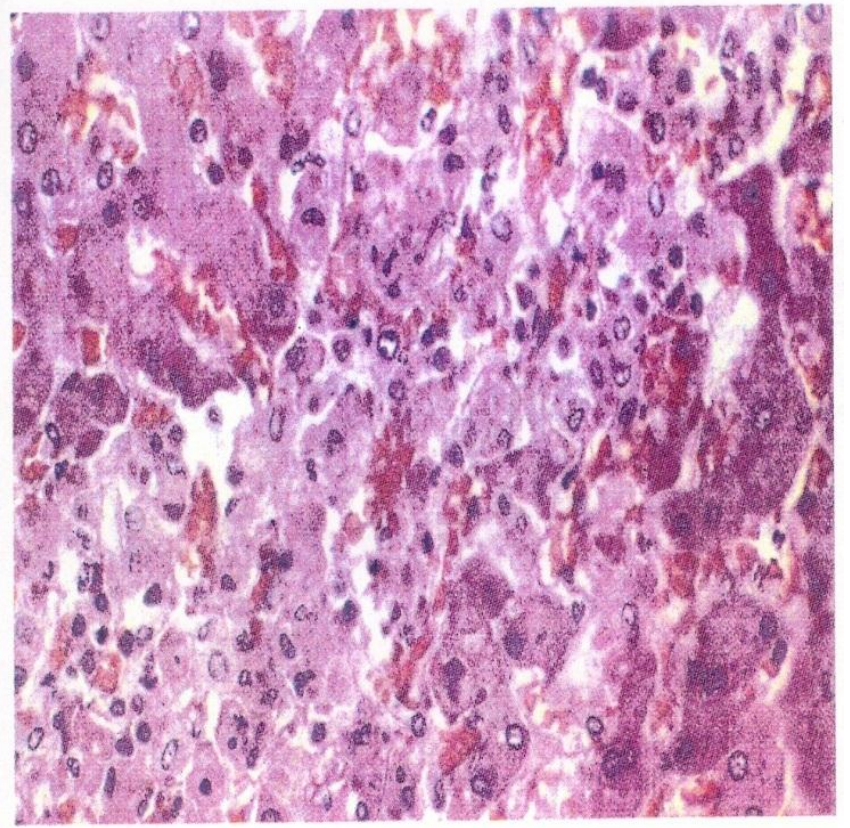

Fig 3: Photomicrograph of liver- showing congestion, edema, portal triradiatis and necrotic and dying hepatocytes, survival period 1 day seen in almost all $(98.08 \%)$ the cases followed by edema $(78.84 \%)$ and portal tri-radiatis $(57.69 \%)$. Edema and portal triradiatis were observed in burn patients after 12 hours, fatty degeneration (44.23\%) after 24 hours and lymphocytic infiltration $(17.30 \%)$ \& centri-venous necrosis $(26.92 \%)$ after 48 hours to burn injuries.

In kidneys beside congestion, prominence of inter-tubular capillaries was found in $50 \%$, cloudy swelling in $25 \%$ \& acute tubular necrosis in $28.84 \%$ cases mostly when died within 24 hours. If patients survived for more than two days lymphocytic infiltration (21.15\%), glomerular/tubular necrosis $(9.61 \%)$ and hemorrhages (7.69\%) appeared in renal tissues.

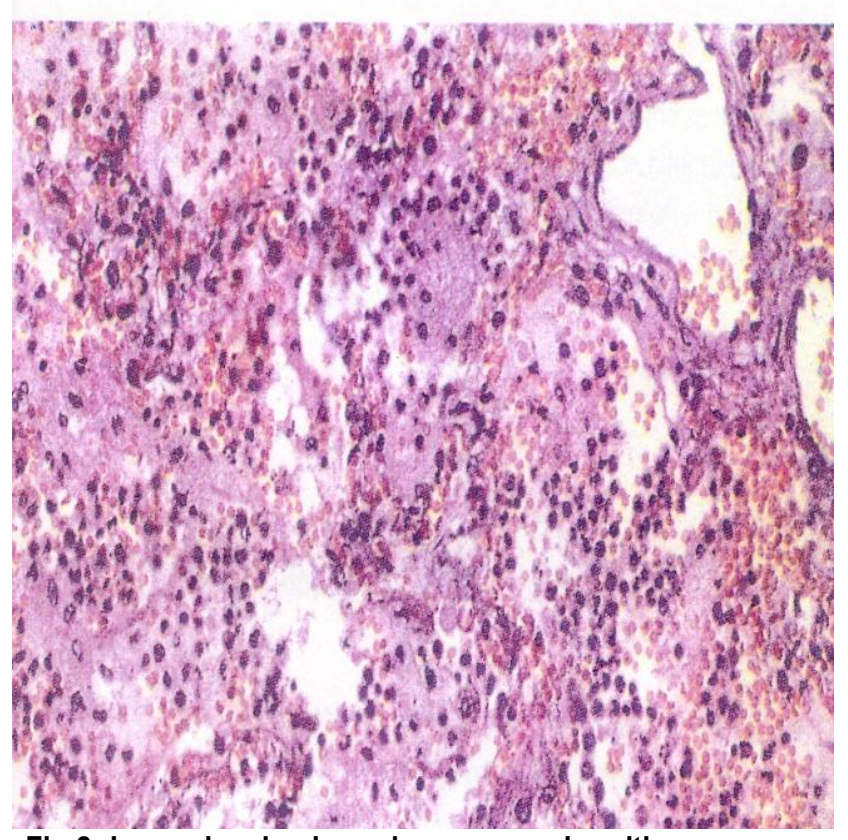

Fig 2: Lung-showing broncho-pneumonia, with numerous polymorphonuclear leucocytes in the pulmonary alveoli, survival period 2 days.

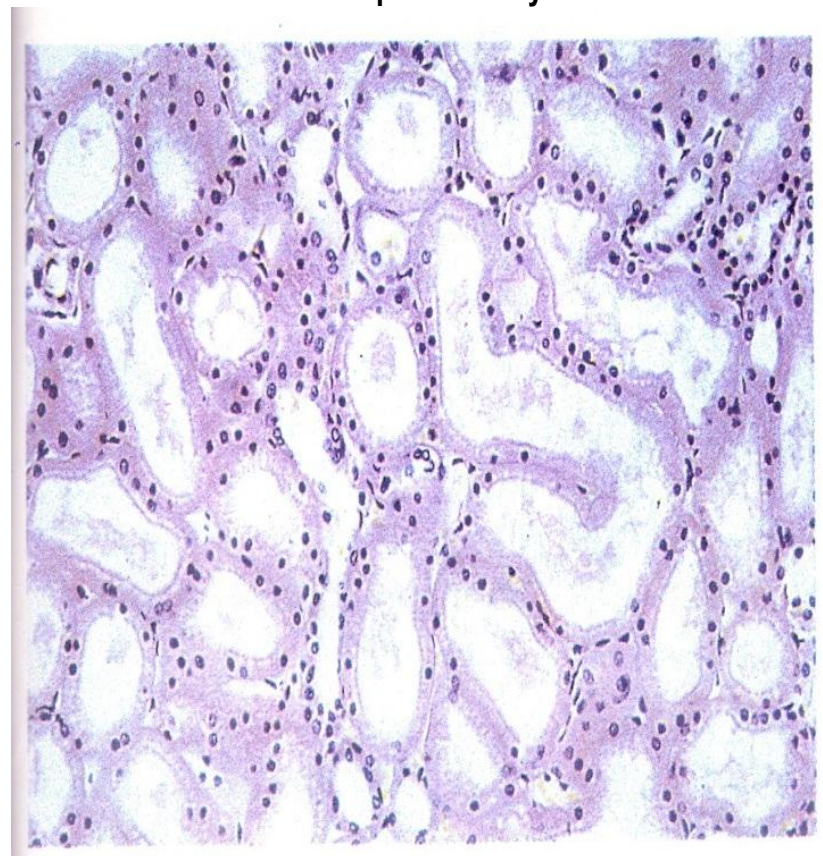

Fig 4: Photomicrograph of kidney-showing tubular dilatations, cloudy swelling with flattening of epithelial cells due to hypovolaemia in burns, survival period 1 day. 
Table 1: Age and gender of burn victims

\begin{tabular}{cccccccc}
\hline & $\begin{array}{c}\text { AGE GROUP (in } \\
\text { years) }\end{array}$ & \multicolumn{2}{c}{ MALES } & \multicolumn{2}{c}{ FEMALES } & \multicolumn{3}{c}{ TOTAL } \\
\cline { 3 - 7 } & & No. & $\%$ & No. & $\%$ & No. & $\%$ \\
1 & $\mathbf{0 - 1 0}$ & - & - & 01 & 1.92 & 01 & 01.92 \\
2 & $11-20$ & 02 & 3.84 & 12 & 23.07 & 14 & 26.92 \\
3 & $21-30$ & 03 & 5.76 & 22 & 42.30 & 25 & 48.07 \\
4 & $31-40$ & 04 & 7.69 & 04 & 7.69 & 08 & 15.38 \\
5 & $41-50$ & 02 & 3.84 & 02 & 3.84 & 04 & 07.69 \\
& TOTAL & 11 & 21.15 & 41 & 78.84 & 52 & 100 \\
\hline
\end{tabular}

Table 2: Source of fire in burn cases

\begin{tabular}{clcc}
\hline S. No. & Source of fire & No. & $\%$ \\
\hline 1. & Kerosene stove & 27 & 51.92 \\
2. & Kerosene oil & 17 & 32.69 \\
3. & Cooking gas & 03 & 05.76 \\
4. & Lamp/candles & 03 & 05.76 \\
$\mathbf{5 .}$ & Electric short circuit & 01 & 01.92 \\
$\mathbf{6 .}$ & Miscellaneous & 01 & 01.92 \\
& Total & 52 & 100 \\
\hline
\end{tabular}

Table 3: Survival period of the victim and their relation to the severity of burn

\begin{tabular}{ccccc}
\hline S.No. & Survival Period & \multicolumn{2}{c}{ Cases } & \multirow{2}{*}{$\begin{array}{c}\text { Severity } \\
\text { (\% of burn) }\end{array}$} \\
\cline { 3 - 4 } & & No. & $\%$ & \\
$\mathbf{1}$ & Brought dead & 02 & 03.84 & 98.00 \\
$\mathbf{2}$ & $<1$ day & 28 & 53.84 & 94.64 \\
$\mathbf{3}$ & $\mathbf{1}-\mathbf{2}$ days & 05 & 09.61 & 90.40 \\
$\mathbf{4}$ & $\mathbf{2}-\mathbf{3}$ days & 05 & 09.61 & 93.40 \\
$\mathbf{5}$ & $\mathbf{3}-\mathbf{5}$ days & 06 & 07.69 & 81.25 \\
$\mathbf{6}$ & $\mathbf{5}-\mathbf{7}$ days & 02 & 03.84 & 76.00 \\
$\mathbf{7}$ & $>\mathbf{7}$ days & 04 & 07.69 & 60.00 \\
Total & & 52 & 100 & -- \\
\hline
\end{tabular}

Table 4: Histo-pathological changes in skin, lung, liver \& kidney in burn cases at different time interval

\begin{tabular}{|c|c|c|c|c|}
\hline $\begin{array}{l}\text { Survival } \\
\text { period }\end{array}$ & Skin & Lung & Liver & Kidneys \\
\hline Brought dead & Congestion & $\begin{array}{l}\text { Congestion \&carbon soot } \\
\text { particles }\end{array}$ & Congestion & Congestion \\
\hline 1-12 hrs. & $\begin{array}{l}\text { Congestion\& edema } \\
\text { in underlying tissues }\end{array}$ & $\begin{array}{l}\text { Congestion, carbon soot } \\
\text { particles\& pulmonary edema }\end{array}$ & Congestion \& edema & Congestion \& edema \\
\hline $13-24 \mathrm{hrs}$. & $\begin{array}{l}\text { Congestion\& edema } \\
\text { in underlying tissues }\end{array}$ & $\begin{array}{l}\text { Congestion, Pulmonary edema } \\
\& \text { hemorrhage }\end{array}$ & $\begin{array}{l}\text { Congestion, edema \& portal } \\
\text { triradiatis }\end{array}$ & $\begin{array}{l}\text { Congestion, edema, cloudy } \\
\text { swelling \&acute tubular necrosis }\end{array}$ \\
\hline $1-2$ days & $\begin{array}{l}\text { Congestion, edema \& } \\
\text { lymphocytic } \\
\text { infiltration }\end{array}$ & $\begin{array}{l}\text { Congestion, pulmonary } \\
\text { edema, hemorrhage } \\
\text { \&Broncho-pneumonia, }\end{array}$ & $\begin{array}{l}\text { Congestion, edema, portal } \\
\text { triradiatis \& fatty changes }\end{array}$ & $\begin{array}{l}\text { Congestion, cloudy swelling, } \\
\text { acute tubular necrosis and } \\
\text { lymphocyte infiltration }\end{array}$ \\
\hline 2-3 days & $\begin{array}{l}\text { Congestion, edema \& } \\
\text { lymphocytic } \\
\text { infiltration }\end{array}$ & $\begin{array}{l}\text { Congestion, pulmonary } \\
\text { edema, Broncho-pneumonia } \\
\text { \&emphysema atelectasis }\end{array}$ & $\begin{array}{l}\text { Congestion, edema, fatty } \\
\text { changes, lymphocytic } \\
\text { infiltration \& centri-venous } \\
\text { necrosis }\end{array}$ & $\begin{array}{l}\text { Congestion, cloudy swelling, } \\
\text { acute tubular necrosis, } \\
\text { lymphocyte infiltration\& } \\
\text { hemorrhagic spots }\end{array}$ \\
\hline 3-5 days & $\begin{array}{l}\text { Congestion, edema } \\
\text { \&lymphocytic } \\
\text { infiltration }\end{array}$ & $\begin{array}{l}\text { Congestion, pulmonary } \\
\text { edema, consolidation } \\
\text { \&emphysema / atelectasis }\end{array}$ & $\begin{array}{l}\text { Congestion, edema, fatty } \\
\text { changes, lymphocytic } \\
\text { infiltration \& centri-venous } \\
\text { necrosis }\end{array}$ & $\begin{array}{l}\text { Congestion, glomerular/ tubular } \\
\text { necrosis, lymphocytic infiltration } \\
\& \text { hemorrhagic spots }\end{array}$ \\
\hline 5-7 days & $\begin{array}{l}\text { Congestion, } \\
\text { lymphocytic } \\
\text { infiltration and } \\
\text { granulation. }\end{array}$ & $\begin{array}{l}\text { Congestion, pulmonary } \\
\text { edema, consolidation } \\
\text { \&emphysema / atelectasis }\end{array}$ & $\begin{array}{l}\text { Congestion, edema, fatty } \\
\text { changes, lymphocytic } \\
\text { infiltration \& centri-venous } \\
\text { necrosis }\end{array}$ & $\begin{array}{l}\text { Congestion, glomerular/ tubular } \\
\text { necrosis, lymphocytic infiltration } \\
\& \text { hemorrhagic spots }\end{array}$ \\
\hline $\begin{array}{l}>7 \text { days } \\
\text { onwards }\end{array}$ & $\begin{array}{l}\text { Congestion, } \\
\text { granulation. }\end{array}$ & $\begin{array}{l}\text { Congestion, consolidation } \\
\text { \&emphysema / atelectasis }\end{array}$ & $\begin{array}{l}\text { Congestion, edema, fatty } \\
\text { changes, lymphocytic } \\
\text { infiltration \& centri-venous } \\
\text { necrosis }\end{array}$ & $\begin{array}{l}\text { Congestion, glomerular/ tubular } \\
\text { necrosis, lymphocytic infiltration } \\
\& \text { hemorrhagic spots }\end{array}$ \\
\hline
\end{tabular}




\section{DISCUSSION}

In this study of 52 cases of burn, majority of the victims are female (78.84\%) and between 21 to 30 years $(48.07 \%)$ of age, which is similar to other studies conducted in Northern India ${ }^{3,4}$. On histopathological examination pulmonary edema (73.07\%), bronchopneumonia (36.53\%), hemorrhage (28.08\%), emphysema (23.53\%), consolidation (17.30\%) etc. are seen in lungs. Such findings were also seen in another study conducted at Wardha, Maharastra ${ }^{5}$. It is also observed that pulmonary edema, bronchopneumonia and hemorrhages appear earlier between 12-24 hours of burn and emphysema, consolidation and atelectasis late after 3 days.

Congestion, edema, cloudy swelling, portal tri-radiatis, fatty degeneration, centri-venous necrosis etc.in liver are the common histo-pathological findings in burns ${ }^{6}$. These are also observed in substantial number of cases in this study too. In kidneys acute tubular necrosis, cloudy swelling and lymphocytic infiltration were observed in $28.84 \%, 25 \%$ and $21.15 \%$ cases respectively, similar to the observation made by Bansal \& Nayak $^{5}$. It was also observed that cloudy swelling \& acute tubular necrosis appear within 24 hours and lymphocytic infiltration \& hemorrhages after 2 days of burn injuries.

\section{CONCLUSIONS}

Histo-pathological changes in skin, lung, liver and kidney were examined in 52 cases died due to burn injuries at different intervals and it was observed that:

- Congestion and edema are the two universal findings present in all four tissues in almost all the cases. This indicates that these changes appear very soon just after burn injuries.

- Beside shoot particles, pulmonary edema, bronchopneumonia and hemorrhages were observed in lung tissues between 12-24 hours after burn injuries and emphysema, consolidation and atelectasis after 3 days.

- In liver edema and portal triradiatis appeared 12 hours after burn, fatty degeneration after 24 hours and lymphocytic infiltration \& centri-venous necrosis after 2 days.
- In kidneys congestion and edema appeared just after burn, cloudy swelling \& acute tubular necrosis within 24 hours and lymphocytic infiltration \& hemorrhages after 2 days.

- This information is helpful in evaluating duration of burn injuries when history and other records are misleading.

\section{REFERENCES}

1. Knight B, Sahai VB, Bapat SK, Yudhishthira, Saxena RN.HWV Cox Medical Jurisprudence and Toxicology. 5th edition, Allahabad: The Law Book Company (P) Ltd; 1987. P. 319-29.

2. Reddy KSN. The Essentials of Forensic Medicine and Toxicology. 24th edition, Hyderabad: K Sugunadevi; 2005. P. 276-77.

3. Gupta RK, Srivastava AK.Study of Fatal burn cases in Kanpur (India). Forensic Science International. 1988; 37: 81-89.

4. Sinha US, Kapoor AK, Agnihotri AK, Srivastava PC.The epidemiological study of dowry death cases with special reference to burn cases in Allahabad Range. International Journal of Med. Toxi. and Legal Medicine. 1998; 1(1): 65-71.

5. Nayak RS, Agarwal S, Tirpude BH, Bansal RS.Detection of soot particles in respiratory passage in cases of death due to burns. Journal of Forensic Medicine \& Toxicology. 1998; 15(1): 5-10.

6. Boyd W. A Textbook of Pathology.7th edition, Philadelphia: Lea \& Febiger; 1962. P.407-8.

\section{Source of Support: Nil.}

Conflict of Interest: None Declared.

Copyright: (c) the author(s) and publisher. IJMRP is an official publication of Ibn Sina Academy of Medieval Medicine \& Sciences, registered in 2001 under Indian Trusts Act, 1882.

This is an open access article distributed under the terms of the Creative Commons Attribution Non-commercial License, which permits unrestricted non-commercial use, distribution, and reproduction in any medium, provided the original work is properly cited.

Cite this article as: Bhim Singh, Srivastava AK. Histo-Pathologic Study of Burn Cases and Its Role in Assessment of Duration of Injuries. Int J Med Res Prof. 2016; 2(3):91-94. 